Jurnal UJMC, Volume 5, Nomor 2, Hal. 49 - 64

pISSN : 2460-3333 eISSN : 2579-907X

\title{
Peningkatan Hasil Belajar Matematika Materi Volume Bangun Ruang Melalui Model Rme Berbasis Teori Bruner Pada Siswa Kelas VI SDN Sidokare 3 Sidoarjo
}

\author{
Purwanti Suhartini ${ }^{1}$
}

${ }^{1}$ SDN Sidokare 3 Sidoarjo, purwanti1964@gmail.com

\begin{abstract}
Based on the initial test of mathematics on the building volume material in $6^{\text {th }}$ students of Sidokare 3 Elementary School shows that students learning outcomes are still under the minimum of KKM score. The problem is caused by the mistakes in calculating and also they don't understand about the formula, some students make mistakes because they less understand the basic of multiplication and division. Another factor is that the teachers used conventional method and also don't to related the problem to the real condition, the teachers don't used the instructional media. An alternative solution by the RME model based on Bruner's theory. This study used a CAR design. The research subject were 32 students. The data collection techniques used test, observation, field notes and documentation. The data analyzed by qualitative and quantitative techniques. The result of this study showed that student learning outcomes in pre-cycle were $41 \%$, cycle I was $75 \%$ and cycle II was 94\%. The conclusion is the application of the RME model based on the Bruner Theory has been proven to be affective in improving student learning outcomes in $6^{\text {th }}$ students of Sidokare 3 Elementary School.
\end{abstract}

Key Words: Learning Outcomes, Mathematics, RME Model, Bruner Theory

\begin{abstract}
Abstrak. Berdasarkan tes awal Matematika materi volume bangun ruang pada siswa kelas VI SDN Sidokare 3 menunjukkan bahwa hasil belajar siswa masih di bawah KKM. Permasalahan tersebut disebabkan siswa masih melakukan kesalahan dalam menghitung volume bangun ruang karena belum memahami rumus atau dalil, sebagian siswa melakukan kesalahan karena tidak menguasai fakta dasar perkalian dan pembagian. Faktor lain guru menggunakan metode konvensional, tidak mengaitkan materi dengan permasalahan nyata, belum menggunakan media pembelajaran. Alternatif pemecahan masalah melalui model RME berbasis teori Bruner. Penelitian ini menggunakan rancangan PTK. Subyek penelitian berjumlah 32 siswa. Teknik pengumpulan data menggunakan teknik tes, observasi, catatan lapangan, dan dokumentasi. Teknik pengumpulan data tersebut, dianalisis dengan teknik kuantitatif dan kualitatif. Hasil penelitian menunjukkan bahwa hasil belajar siswa pada prasiklus sebesar 41\%, siklus I sebesar 75\%, dan siklus II sebesar $94 \%$. Kesimpulannya bahwa penerapan model RME berbasis teori Burner terbukti efektif meningkatkan hasil belajar siswa kelas VI SDN Sidokare 3 Sidoarjo.
\end{abstract}

Kata Kunci : Hasil Belajar, Matematika, Model RME, Teori Bruner. 


\section{PENDAHULUAN}

Pembelajaran matematika di SD dalam Kurikulum 2013 diarahkan untuk mendorong siswa mencari tahu dari berbagai sumber, mampu merumuskan masalah bukan hanya menyelesaikan masalah sederhana dalam kehidupan seharihari. Disamping itu, pembelajaran diarahkan untuk melatih siswa berpikir logis dan kreatif bukan sekedar berpikir mekanistis serta mampu bekerja sama dan berkolaborasi dalam menyelesaikan masalah (Kemendikbud, 2017:3).

Sebagaimana tujuan pendidikan Matematika di atas, dalam melaksanakan proses pembelajaran Matematika diharapkan guru memperhatikan prinsip-prinsip pengembangan Kurikulum 2013 sebagaimana dalam Permendikbud Nomor 57 Tahun 2014 tentang Kurikulum 2013 SD/MI antara lain: 1) Penguatan pola pembelajaran yang berpusat pada peserta didik. Peserta didik harus memiliki pilihan-pilihan terhadap materi yang dipelajari dan gaya belajarnya (learning style) untuk memiliki kompetensi yang sama; 2) Penguatan pola pembelajaran interaktif (interaktif guru-peserta didik-masyarakat-lingkungan alam, sumber/ media lainnya); 3) Penguatan pola pembelajaran secara jejaring (peserta didik dapat menimba ilmu dari siapa saja dan dari mana saja yang dapat dihubungi serta diperoleh melalui internet); 4) Penguatan pembelajaran aktif-mencari (pembelajaran siswa aktif mencari semakin diperkuat dengan pendekatan pembelajaran saintifik); 5) Penguatan pola belajar sendiri dan kelompok (berbasis tim); 6) Penguatan pembelajaran berbasis multimedia; 7) Penguatan pola pembelajaran ilmu pengetahuan jamak (multidisciplines); 8) Penguatan pola pembelajaran berbasis klasikal-massal dengan tetap memperhatikan pengembangan potensi khusus yang dimiliki setiap peserta didik; dan 9) Penguatan pola pembelajaran kritis.

Dalam melaksanakan proses pembelajaran Matematika yang sesuai dengan prinsip-prinsip Kurikulum 2013 di atas, guru harus menguasai empat dimensi kompetensi sebagaimana tertuang dalam Permendiknas Nomor 16 Tahun 2007 tentang Standar Kualifikasi Akademik dan Kompetensi Guru menjelaskan bahwa kompetensi yang harus dimiliki guru meliputi kompetensi pedagogik, kompetensi kepribadian, kompetensi sosial, dan kompetensi profesional.

Kompetensi guru yang paling utama yang harus dikuasai dalam melaksanakan proses pembelajaran Matematika di SD yaitu kompetensi pedagogik dan profesional. Kompetensi pedagogik yang harus dikuasai yaitu pemahaman terhadap peserta didik, perancangan peserta didik untuk mengaktualisasikan berbagai potensi yang dimilikinya. Kompetensi profesional yang harus dikuasai yaitu penguasaan materi pembelajaran secara luas dan mendalam yang memungkinkan membimbing peserta didik memenuhi standar kompetensi yang ditetapkan dalam SNP.

Matematika diajarkan di SD mempunyai sifat deduktif dan objek kajiannya abstrak. Jika sifat matematika ini dikaitkan dengan taraf berpikir siswa Sekolah Dasar yang masih berada dalam tahap berpikir konkrit maka akan terjadi kesenjangan yang mengakibatkan kegagalan dalam mempelajarinya. Kegagalan yang dimaksud salah satunya berupa hasil belajar yang belum mencapai KKM, seperti yang terjadi pada siswa kelas VI SDN Sidokare 3 Sidoarjo pada mata pelajaran Matematika materi volume bangun ruang. Berdasarkan tes hasil evaluasi materi volume bangun ruang, hasil belajar yang dicapai siswa masih jauh dari 
harapan yaitu dari 32 siswa hanya 13 siswa saja atau $41 \%$ yang mendapat nilai 75 ke atas sedangkan sisanya 19 siswa atau 59\% mendapat nilai di bawah 75 atau di bawah KKM yang telah ditentukan sekolah sebesar 75 .

Permasalahan tersebut disebabkan karena siswa masih melakukan kesalahan dalam menghitung volume bangun ruang. Hal ini dikarenakan siswa dalam menghitung volume jika tidak diketahui tinggi atau alasnya, tidak menggunakan dalil atau rumus phytagoras namun langsung menggunakan rumus volume. Selain itu sebagian siswa melakukan kesalahan dalam menghitung volume bangun ruang karena tidak menguasai fakta dasar perkalian dan pembagian. Faktor lain proses pembelajaran yang masih menerapkan model konvensional, di mana guru menjelaskan suatu konsep kemudian siswa hanya duduk mendengarkan. Suasana kelas cenderung berpusat pada guru, sehingga siswa menjadi pasif, tidak dapat berpikir kritis, kurang berani untuk bertanya, menjawab pertanyaan, dan mengemukakan pendapatnya saat pembelajaran berlangsung. Guru juga kurang mengaitkan penyampaian materi pembelajaran dengan permasalahan nyata dalam kehidupan sehari-hari siswa. Dalam penyampaian materi volume bangun ruang, guru langsung menjelaskan konsep volume bangun ruang yang harus diketahui siswa. Hal ini menjadikan siswa kurang diberi kesempatan untuk menyusun pengetahuannya sendiri.

Dalam proses belajarnya, siswa masih memahami suatu konsep melalui apa yang dilihat secara nyata atau konkret. Dalam kehidupan sehari-hari, siswa selalu menemukan dan berhubungan dengan berbagai permasalahan maupun objek nyata yang berkaitan dengan Matematika. Oleh karena itu, seorang guru SD harus kreatif dan inovatif dalam membelajarkan Matematika kepada siswa, misalnya dalam menggunakan alat peraga dan pemberian permasalahan yang nyata atau konkret yang berkaitan dengan konteks kehidupan nyata di sekitar lingkungan siswa. Melalui pemberian ilustrasi serta contoh konkret wujud benda nyata yang ada di sekitar siswa, maka konsep abstrak menjadi lebih mudah dipahami oleh siswa dalam mengikuti pembelajaran. Pembelajaran Matematika yang dirancang dan dilaksanakan secara monoton dan tanpa adanya penerapan model pembelajaran yang inovatif dapat mengakibatkan siswa kurang termotivasi dalam memahami materi yang diberikan oleh guru. Dengan pemilihan model pembelajaran yang sesuai dengan karakteristik siswa, mata pelajaran, dan kurikulum, maka akan membantu pencapaian hasil belajar siswa yang optimal.

Salah satu alternatif yang akan peneliti lakukan dalam meningkatkan hasil belajar Matematika materi volume bangun ruang sesuai dengan kriteria yang ditetapkan, yakni dengan menerapkan model Realistic Mathematics Education (RME) berbasis Teori Bruner. Menurut Hadi (dalam Aisyah, dkk., 2010:7.3) mengemukakan bahwa pembelajaran dengan menerapkan model RME merupakan model pembelajaran yang dilakukan melalui penjelajahan berbagai situasi dan masalah-masalah realistik atau nyata yang ada di lingkungan sekitar siswa. Masalah-masalah nyata dari kehidupan sehari-hari tersebut digunakan sebagai titik awal pembelajaran matematika untuk menunjukkan bahwa Matematika sebenarnya dekat dengan kehidupan sehari-hari. Model ini bertitik tolak dari halhal yang riil (nyata) bagi siswa, menekankan keterampilan "process of doing mathematics", berdiskusi dan berkolaborasi, berargumentasi, dan pada akhirnya 
siswa dapat menggunakan matematika untuk menyelesaikan masalah baik secara individu maupun kelompok.

Pemilihan model RME dalam penelitian ini, dikarenakan adanya kelebihan dalam penerapan model pembelajaran tersebut. Model RME mempunyai beberapa kelebihan antara lain: 1) Siswa membangun sendiri pengetahuan, sehingga siswa tidak mudah lupa dengan pengetahuannya; 2) Suasana proses pembelajaran menyenangkan karena menggunakan realitas kehidupan, sehingga siswa tidak cepat bosan belajar matematika; 3) Siswa merasa dihargai dan semakin terbuka, karena setiap jawaban siswa ada nilainya; 4) Memupuk kerja sama dalam kelompok; 5) Melatih keberanian siswa dalam menjelaskan jawabannya; 6) Melatih siswa untuk terbiasa berpikir dan mengemukakan pendapat (Aisyah, dkk., 2010:7.21).

Selain penerapan model RME, dalam mengenalkan konsep Matematika kepada siswa menurut Bruner dapat dilakukan melalui tiga model tahapan di antaranya model tahap enaktif yaitu model tahap pembelajaran Matematika yang penyajiannya dilakukan melalui benda-benda konkrit atau menggunakan situasi yang nyata, model tahap ikonik yaitu pembelajaran Matematika yang penyajiannya direpresentasikan dalam bentuk bayangan visual yang menggambarkan situasi konkrit, dan model tahap simbolik yaitu pembelajaran Matematika direpresentasikan dalam bentuk simbol atau lambang yang abstrak (Winataputra, dkk., 2016: 3.42-3.43).

Kecocokan pembelajaran Matematika realistik jika dikaitkan dengan teori belajar Bruner, yakni pada proses kegiatan pembelajaran sangat dimungkinkan siswa memanipulasi objek-objek yang ada kaitannya dengan masalah-masalah kontekstual yang diberikan guru secara langsung sehingga para siswa dapat memahami hubungan antara konsep-konsep dan struktur-struktur Matematika.

Berdasarkan latar belakang masalah di atas, maka peneliti mengadakan upaya peningkatan hasil belajar Matematika materi volume bangun ruang melalui penelitian dengan judul "Peningkatan Hasil Belajar Matematika Materi Volume Bangun Ruang Melalui Model RME Berbasis Teori Bruner Pada Siswa Kelas VI SDN Sidokare 3 Sidoarjo".

\section{KAJIAN PUSTAKA}

\subsection{Hasil Belajar}

Hasil belajar adalah segala sesuatu menjadi milik siswa sebagai akibat dari kegiatan pembelajaran yang dilakukan. Dalam kegiatan pembelajaran, hasil belajar dinyatakan dalam rumusan tujuan. Tujuan belajar dibagi menjadi tiga meliputi kognitif, afektif, dan psikomotor (Hernawan, dkk, 2016:10.20). Bloom, dkk (dalam Hernawan, dkk, 2016:10.23-10.32), hasil belajar digolongkan menjadi tiga domain yaitu ranah kognitif (pengetahuan), afektif (sikap), dan psikomotorik (keterampilan). Anitah, dkk (2014:2.7) menjelaskan bahwa keberhasilan belajar sangat dipengaruhi oleh beberapa faktor. Faktor-faktor tersebut dapat dikelompokkan menjadi dua kelompok yaitu faktor dalam diri siswa sendiri (intern) dan faktor dari luar diri siswa (ekstern). Faktor dari dalam diri siswa yang berpengaruh terhadap hasil belajar diantaranya adalah kecakapan, minat, bakat, usaha, motivasi, perhatian, kelemahan dan kesehatan, serta kebiasaan siswa. 
Faktor dari luar diri siswa yang mempengaruhi hasil belajar diantaranya adalah lingkungan fisik dan nonfisik (termasuk suasana kelas dalam belajar, seperti riang gembira, menyenangkan), lingkungan sosial budaya, lingkungan keluarga, program sekolah, guru, pelaksanaan pembelajaran, dan teman sekolah.

\subsection{Matematika}

Matematika adalah ilmu deduktif, asiomatik, formal, hirarkis, abstrak, bahasa simbol yang padat arti semacamnya, sehingga para ahli matematika dapat mengembangkan sebuah sistem matematika. Dalam matematika pengembangan model-model matematika dapat digunakan untuk mengatasi persoalan-persoalan dunia nyata dan dapat membentuk pola berpikir seseorang menjadi pola pikir yang sistematis, logis, kritis dan penuh kecermatan (Karso, dkk, 2014:1.59). Ruang lingkup Matematika SD ada tiga yaitu 1) Bilangan (bilangan cacah, bulat, prima, pecahan, kelipatan dan faktor, pangkat dan akar sederhana) dalam penyelesaian masalah kehidupan sehari-hari; 2) Geometri dan pengukuran (bangun datar dan bangun ruang, hubungan antar garis, pengukuran (berat, panjang, luas, volume, sudut, waktu, kecepatan, dan debit, letak dan koordinat suatu benda) dalam penyelesaian masalah kehidupan sehari-hari, serta; 3) Statistika (menyajikan dan menafsirkan data tunggal) dalam penyelesaian masalah kehidupan sehari-hari (Kemendikbud, 2017:3).

\subsection{Model Realistic Mathematics Education (RME)}

Menurut Hadi (dalam Aisyah, dkk., 2010:7.3) mengemukakan bahwa model RME merupakan model pembelajaran yang dilakukan melalui penjelajahan berbagai situasi dan masalah-masalah realistik atau nyata yang ada di lingkungan sekitar siswa. Lebih lanjut menurut Aisyah, dkk (2010:7.21) bahwa model RME mempunyai beberapa kelebihan antara lain: 1) Siswa membangun sendiri pengetahuan, sehingga siswa tidak mudah lupa dengan pengetahuannya; 2) Suasana proses pembelajaran menyenangkan karena menggunakan realitas kehidupan, sehingga siswa tidak cepat bosan belajar matematika; 3) Siswa merasa dihargai dan semakin terbuka, karena setiap jawaban siswa ada nilainya; 4) Memupuk kerja sama dalam kelompok; 5) Melatih keberanian siswa dalam menjelaskan jawabannya; 6) Melatih siswa untuk terbiasa berpikir dan mengemukakan pendapat.

\subsection{Teori Bruner}

Menurut Bruner (dalam Aisyah, 2010:1.5) menyatakan belajar merupakan suatu proses aktif yang memungkinkan manusia untuk menemukan hal-hal baru di luar informasi yang diberikan kepada dirinya. Ada tiga proses kognitif yang terjadi dalam belajar, yaitu proses perolehan informasi baru, proses mentransformasikan informasi yang diterima, dan menguji relevansi dan ketepatan pengetahuan. Teori belajar Bruner (dalam Winataputra, dkk., 2016:3.42-3.43) terdiri dari tiga tahap yaitu: 1) tahap enaktif yaitu tahap pembelajaran yang penyajiannya dilakukan melalui benda-benda konkrit atau menggunakan situasi yang nyata; 2) tahap ikonik yaitu pembelajaran yang penyajiannya direpresentasikan dalam bentuk bayangan visual yang 
menggambarkan situasi konkrit; 3) tahap simbolik yaitu pembelajaran direpresentasikan dalam bentuk simbol atau lambang yang abstrak.

\section{METODE PENELITIAN}

\subsection{Rancangan Penelitian}

Penelitian ini menggunakan pendekatan Penelitian Tindakan Kelas (PTK). Menurut Suyanto (dalam Sukajati, 2012:8) secara singkat PTK dapat didefinisikan sebagai suatu bentuk penelitian yang bersifat reflektif dengan melakukan tindakan-tindakan tertentu, untuk memperbaiki dan atau meningkatkan praktekpraktek pembelajaran di kelas secara lebih profesional. Oleh karena itu PTK terkait erat dengan persoalan praktek pembelajaran sehari-hari yang dialami guru.

Lebih lanjut Sukajati (2012:12-13) menjelaskan bahwa tujuan utama dilaksanakan PTK antara lain: 1) Meningkatkan dan memperbaiki praktek pembelajaran yang seharusnya dilakukan oleh guru, mengingat masyarakat kita berkembang begitu cepat; 2) Meningkatkan mutu pendidikan. Peningkatan atau perbaikan praktek pembelajaran di kelas hanya tujuan antara, sedangkan tujuan akhir adalah peningkatan mutu pendidikan; 3) Menumbuhkembangkan budaya akademik di lingkungan sekolah sehingga tercipta sikap proaktif untuk memperbaiki pembelajaran, berdasar pada persoalan-persoalan pembelajaran yang dihadapi guru di kelas.

Model PTK yang pilih yaitu model PTK Kemmis \& Mc Taggart (dalam Sukajati, 2012:18) berupa perangkat-perangkat atau untaian dengan setiap perangkat terdiri dari empat komponen yaitu perencanaan, tindakan, pengamatan, dan refleksi yang dipandang sebagai suatu siklus.

1. Refleksi Awal

Berdasarkan hasil refleksi awal menunjukkan bahwa hasil belajar matematika materi volume bangun ruang siswa kelas VI SDN Sidokare 3 masih belum mencapai ketuntasan yang dikehendaki. Permasalahan tersebut disebabkan karena siswa masih melakukan kesalahan dalam menghitung volume bangun ruang karena belum memahami rumus atau dalil, sebagian siswa melakukan kesalahan karena tidak menguasai fakta dasar perkalian dan pembagian. Guru menggunakan metode konvensional, tidak mengaitkan materi pembelajaran dengan permasalahan nyata, belum menggunakan media pembelajaran.

2. Perencanaan

Pada tahap perencanaan ini peneliti melakukan kegiatan perencanaan antara lain: 1) Menyusun RPP mata pelajaran Matematika materi volume bangun ruang melalui model RME berbasis teori Bruner; 2) Menyiapkan benda konkrit dan gambar bangun ruang; 3) Menyiapkan lembar observasi dan berbagai instrumen pengumpul data yang akan digunakan dalam penelitian; 4) Menyiapkan alat evaluasi yang berupa soal tes tulis beserta kunci jawabannya.

3. Pelaksanaan Tindakan

Pada tahap pelaksanaan tindakan dalam penelitian ini dengan melaksanakan perencanaan yang telah dibuat, yakni dengan melaksanakan pembelajaran Matematika materi volume bangun ruang melalui model RME berbasis teori Bruner. Penelitian ini dilaksanakan dalam dua siklus, masing- 
masing siklus terdiri dari kegiatan pendahuluan, kegiatan inti, dan kegiatan penutup.

4. Pengamatan

Pada tahap pengamatan dalam penelitian ini dilaksanakan secara kolaboratif untuk mengamati hasil belajar Matematika materi volume bangun ruang pada siswa kelas VI SDN Sidokare 3 Sidoarjo melalui model RME berbasis teori Bruner berupa tes tulis, serta observasi aktivitas guru dan sikap siswa selama proses pembelajaran berlangsung.

5. Refleksi

Pada tahap refleksi dalam penelitian ini, peneliti mengkaji hasil belajar Matematika materi volume bangun ruang pada siswa kelas VI SDN Sidokare 3 Sidoarjo melalui model RME berbasis teori Bruner, serta aktivitas guru dan sikap siswa. Peneliti juga mengkaji apakah pembelajaran sudah berjalan efektif dengan mengkaji kekurangan dan membuat daftar permasalahan yang muncul selama pelaksanaan tindakan. Setelah itu, peneliti dan mitra kolaborator membuat perencanaan tindak lanjut untuk siklus berikutnya berdasarkan daftar permasalahan tersebut, dalam rangka perbaikan untuk mencapai indikator yang ditetapkan.

\subsection{Subyek dan Lokasi Penelitian}

Subjek penelitian ini adalah siswa kelas VI SDN Sidokare 3 Sidoarjo Tahun Pelajaran 2017-2018, dengan jumlah 32 siswa yang terdiri dari 15 siswa laki-laki dan 17 siswa perempuan. Lokasi penelitian berada di SDN Sidokare 3 tepatnya berada di Jalan Sekolahan No. 40 Kelurahan Sidokare Kecamatan Sidoarjo Kabupaten Sidoarjo. Waktu penelitian dilaksanakan pada semester II tahun pelajaran 2017-2018 bulan Januari sampai dengan Maret 2018.

\subsection{Teknik Pengumpulan Data}

Teknik pengumpulan data pada penelitian ini menggunakan teknik tes dan teknik nontes. Uraian teknik pengumpulan data dapat dijelaskan sebagai berikut. Teknik tes digunakan untuk mengetahui peningkatan hasil belajar Matematika materi volume bangun ruang pada siklus I dan siklus II. Langkah-langkah yang dilakukan dalam pengambilan data dengan teknik tes yaitu: 1) Menyiapkan lembar kerja dan lembar evaluasi beserta kunci jawaban; 2) Memberikan tes keseluruh subyek penelitian, baik secara individu maupun kelompok; 3) Mengumpulkan lembar jawaban yang sudah diselesaikan oleh subyek penelitian; 4) Mengoreksi jawaban subyek penelitian berdasarkan kunci jawaban, dan lembar penilaian yang berisikan indikator pencapaian kompetensi siswa.

Observasi yang digunakan dalam penelitian ini adalah observasi aktivitas guru dan siswa dalam proses pembelajaran yang telah direncanakan pada siklus I dan siklus II. Langkah-langkah yang dilakukan dalam pengambilan data dengan teknik observasi yaitu: 1) Menyiapkan lembar observasi aktivitas guru dan sikap siswa; 2) Melaksanakan observasi selama proses pembelajaran berlangsung dengan dibantu mitra kolaborator; 3) Mencatat hasil observasi dengan mengisi lembar observasi yang telah disiapkan. 
Dokumentasi yang digunakan dalam penelitian ini berupa foto. Dokumentasi foto dalam proses pembelajaran dijadikan gambaran aktivitas guru dan sikap siswa dalam penelitian yang telah direncanakan pada siklus I dan siklus II. Langkah-langkah yang dilakukan dalam pengambilan data dengan teknik dokumentasi foto yaitu: 1) Menyiapkan kamera yang akan digunakan untuk mendokumentasikan kegiatan yang berlangsung selama pembelajaran; 2) Memotret setiap kegiatan/ aktivitas dalam proses pembelajaran; 3) Memilah dan memilih foto yang akan digunakan dalam penelitian ini.

Catatan lapangan dalam penelitian ini ditulis oleh pengamat untuk mendeskripsikan proses pembelajaran yang telah direncanakan pada siklus I dan siklus II. Langkah-langkah yang dilakukan dalam pengambilan data dengan teknik catatan lapangan yaitu: 1) Menyiapkan lembar catatan lapangan dan petunjuk pengisiannya; 2) Mencatat kelebihan dan kelemahan proses pembelajaran; dan 3) Merefleksikan kelebihan dan kelemahan sebagai bahan perbaikan pembelajaran atau tindak lanjut.

\subsection{Teknik Analisis Data}

Analisis data kuantitatif diperoleh dari analisis nilai tes hasil belajar Matematika materi volume bangun ruang melalui model RME berbasis teori Bruner pada siswa kelas VI SDN Sidokare 3 Sidoarjo. Rumus-rumus yang digunakan untuk mengolah data kuantitatif dapat dijelaskan sebagai berikut.

1. Menentukan nilai akhir hasil belajar siswa.

$$
N A=\frac{\sum \mathrm{X}}{M}
$$

Keterangan:

NA $=$ Nilai Akhir

$\sum \mathrm{X}=$ Jumlah keseluruhan skor yang diperoleh

M = Jumlah keseluruhan skor maksimal (Djamarah, 2015:331)

2. Menentukan rata-rata kelas.

$$
N r=\frac{\sum \mathrm{Na}}{\mathrm{Sn}}
$$

Keterangan:

$\mathrm{Nr}=$ Nilai rata-rata

$\sum \mathrm{Na}=$ Jumlah nilai akhir semua siswa

$\mathrm{Sn}=$ Jumlah siswa (Djamarah, 2015:332)

3. Menentukan persentase ketuntasan belajar siswa.

$$
P=\frac{\mathrm{F}}{N} \times 100 \%
$$

Keterangan:

$\mathrm{P}=$ Persentase ketuntasan belajar dalam persen

$\mathrm{F}$ = Jumlah siswa yang tuntas belajar

$\mathrm{N}$ = Jumlah seluruh siswa (Djamarah, 2015:264) 
Berdasarkan penghitungan melalui teknik kualitatif di atas, hasil penghitungan tes hasil belajar seluruh siswa dikategorikan dengan pedoman penskoran dan ketuntasan belajar yang sudah ditetapkan. Indikator keberhasilan terhadap hasil belajar siswa mengalami ketuntasan belajar minimal mendapat nilai 75 atau mencapai 75\% secara individual dan mencapai 85\% secara klasikal.

Analisis data kualitatif dalam penelitian ini dilakukan melalui tiga kegiatan utama seperti yang disarankan oleh Miles dan Huberman (dalam Sugiyono, 2013:337) yaitu reduksi data (data reduction), penyajian data (data display), serta penarikan kesimpulan/ verifikasi (conclusion drawing/verification). Berikut ini bagan teknik analisis data model Miles dan Hubberman.

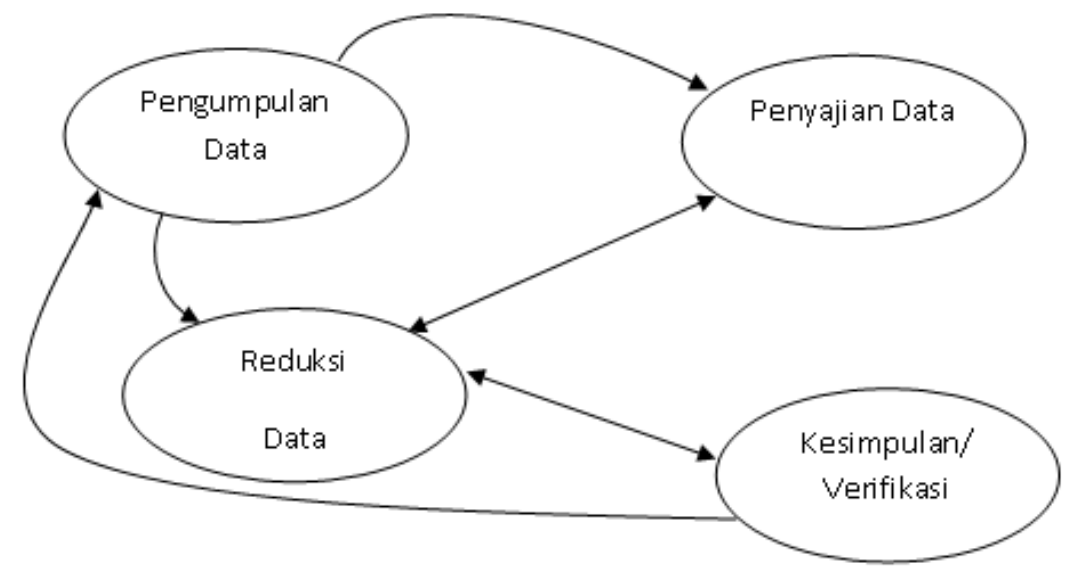

Gambar 1. Komponen Dalam Analisis Data (Sugiyono, 2013:337)

Skema di atas jika diterapkan dalam penelitian ini berarti data dikumpulkan berupa observasi, catatan lapangan, dan dokumentasi dari informan berkaitan dengan hasil belajar siswa. Setelah data terkumpul kemudian menganalisis hasil belajar siswa. Proses analisis data sekaligus mereduksi data guna menyeleksi data, dalam hal ini dilakukan penyederhanaan data-data yang ada. Dari data yang dikelompokkan, dipisahkan antara hasil belajar siswa, aktivitas guru, dan sikap siswa. Untuk menarik kesimpulan, data yang telah dikelompokkan disajikan dalam bentuk kalimat, yang difokuskan pada hasil belajar siswa.

Setelah dilakukan analisis data, selanjutnya melakukan pengecekan keabsahan data melalui triangulasi data. Menurut Sugiyono (2013:330) menjelaskan bahwa triangulasi diartikan sebagai teknik pengumpulan data yang bersifat menggabungkan data dari berbagai teknik pengumpulan data dan sumber data yang telah ada. Dalam proses triangulasi ini, peneliti melakukan dengan berbagai cara membandingkan data hasil tes dengan data observasi, catatan lapangan, dan dokumentasi atau sebaliknya.

Untuk menetapkan keabsahan data diperlukan teknik pemeriksaan data. Pelaksanaan teknik pemeriksaan berdasarkan atas sejumlah kriteria tertentu, ada empat kriteria yang digunakan yaitu: derajat kepercayaan (cerdibility), keteralihan (transferability), ketergantungan (dependability), dan kepastian (confirmability).

Berdasarkan dari ketiga kriteria yang telah disebutkan sebelumnya, peneliti melakukan pengecekan data berdasarkan sumber data yang telah dikumpulkan. 
Pengecekan data tersebut dilakukan secara teliti sehingga diharapkan hasil penelitian yang dilakukan merupakan penelitian benar-benar sah dan orisinal.

\section{HASIL PENELITIAN DAN PEMBAHASAN}

\subsection{Hasil Penelitian}

\section{Pra Siklus}

Dari hasil analisis pretest terhadap hasil belajar Matematika materi volume bangun ruang pada siswa kelas VI SDN Sidokare 3 Sidoarjo dapat diketahui tingkat hasil belajar siswa pada pra siklus sebagai berikut.

Tabel 1. Rekapitulasi Hasil Belajar Siswa Pra Siklus

\begin{tabular}{|c|c|c|c|c|}
\hline No & $\begin{array}{c}\text { Aspek Hasil } \\
\text { Belajar }\end{array}$ & Rerata & Kategori & $\begin{array}{c}\text { Ketuntasan } \\
\text { Klasikal }\end{array}$ \\
\hline 1 & Pengetahuan & 68 & Kurang & \multirow{3}{*}{$41 \%$} \\
\hline 2 & Keterampilan & 68 & Kurang & \\
\hline 3 & Sikap & 2 & Cukup & \\
\hline
\end{tabular}

Sumber : Hasil Penelitian diolah (2018)

Pada tabel 1 dapat diketahui bahwa hasil belajar aspek pengetahuan siswa kelas VI SDN Sidokare 3 pada pra siklus mendapatkan rata-rata nilai klasikal sebesar 68 yang termasuk dalam kategori Kurang yaitu berada pada rentang nilai 75 <. Hasil belajar aspek keterampilan siswa mendapatkan rata-rata nilai klasikal sebesar 68 yang termasuk dalam kategori Kurang yaitu berada pada rentang nilai 75 <. Hasil belajar aspek sikap siswa mendapatkan rata-rata nilai klasikal sebesar 2 yang termasuk dalam kategori Cukup yaitu berada pada rentang nilai 2.

Persentase ketuntasan belajar siswa kelas VI SDN Sidokare 3 Sidoarjo dalam pembelajaran Matematika materi volume bangun ruang pada pra siklus dari 32 siswa terdapat $41 \%$ atau ada 13 siswa yang sudah tuntas belajar secara klasikal, sedangkan siswa yang belum tuntas sebanyak 19 siswa atau 59\%. Hasil tersebut menunjukkan bahwa pada prasiklus secara klasikal siswa belum tuntas belajar, karena siswa yang memperoleh nilai $\geq 75$ hanya sebesar $41 \%$ lebih kecil dari persentase ketuntasan yang dikehendaki.

\section{Siklus I}

Setelah menerapkan model RME berbasis teori Bruner dalam pembelajaran Matematika materi volume bangun ruang diperoleh data hasil belajar siswa pada tindakan siklus I sebagai berikut.

Tabel 2. Rekapitulasi Hasil Belajar Siswa Siklus I

\begin{tabular}{|c|c|c|c|c|}
\hline No & $\begin{array}{l}\text { Aspek Hasil } \\
\text { Belajar }\end{array}$ & Rerata & Kategori & $\begin{array}{c}\text { Ketuntasan } \\
\text { Klasikal }\end{array}$ \\
\hline 1 & Pengetahuan & 79 & Cukup & \multirow{3}{*}{$75 \%$} \\
\hline 2 & Keterampilan & 79 & Cukup & \\
\hline 3 & Sikap & 3 & Baik & \\
\hline
\end{tabular}

Sumber : Hasil Penelitian diolah (2018) 
Pada tabel 2 dapat diketahui bahwa hasil belajar aspek pengetahuan siswa kelas VI SDN Sidokare 3 pada siklus I mendapatkan rata-rata nilai klasikal sebesar 79 yang termasuk dalam kategori Cukup yaitu berada pada rentang nilai $75 \leq$ Nilai $\leq 82$. Hasil belajar aspek keterampilan siswa mendapatkan rata-rata nilai klasikal sebesar 83 yang termasuk dalam kategori Cukup yaitu berada pada rentang nilai $75 \leq$ Nilai $\leq 82$. Hasil belajar aspek sikap siswa mendapatkan ratarata nilai klasikal sebesar 3 yang termasuk dalam kategori Baik yaitu berada pada rentang nilai 3.

Persentase ketuntasan belajar siswa kelas VI SDN Sidokare 3 Sidoarjo dalam pembelajaran Matematika materi volume bangun ruang melalui model RME berbasis teori Bruner pada siklus I dari 32 siswa terdapat 75\% atau ada 24 siswa yang sudah tuntas belajar secara klasikal, sedangkan siswa yang belum tuntas sebanyak 8 siswa atau $25 \%$. Hasil tersebut menunjukkan bahwa pada siklus I secara klasikal siswa belum tuntas belajar, karena siswa yang memperoleh nilai $\geq 75$ hanya sebesar $75 \%$ lebih kecil dari persentase ketuntasan yang dikehendaki.

\section{Siklus II}

Setelah menerapkan model RME berbasis teori Bruner dan melaksanakan hasil refleksi siklus I dalam pembelajaran Matematika materi volume bangun ruang diperoleh data hasil belajar siswa pada tindakan siklus II sebagai berikut.

Tabel 3. Rekapitulasi Hasil Belajar Siswa Siklus II

\begin{tabular}{|c|l|c|c|c|}
\hline No & $\begin{array}{c}\text { Aspek Hasil } \\
\text { Belajar }\end{array}$ & Rerata & Kategori & $\begin{array}{c}\text { Ketuntasan } \\
\text { Klasikal }\end{array}$ \\
\hline 1 & Pengetahuan & 90 & Baik & \multirow{2}{*}{$94 \%$} \\
\cline { 1 - 4 } 2 & Keterampilan & 90 & Baik & \multirow{2}{*}{$94 \%$} \\
\hline 3 & Sikap & 4 & Sangat Baik & \\
\hline
\end{tabular}

Sumber : Hasil Penelitian diolah (2018)

Pada tabel 3 dapat diketahui bahwa hasil belajar aspek pengetahuan siswa kelas VI SDN Sidokare 3 Sidoarjo pada siklus II mendapatkan rata-rata nilai klasikal sebesar 90 yang termasuk dalam kategori Baik yaitu berada pada rentang nilai $83 \leq$ Nilai $\leq 91$. Hasil belajar aspek keterampilan siswa mendapatkan ratarata nilai klasikal sebesar 90 yang termasuk dalam kategori Baik yaitu berada pada rentang nilai $83 \leq$ Nilai $\leq 91$. Hasil belajar aspek sikap siswa mendapatkan rata-rata nilai klasikal sebesar 4 yang termasuk dalam kategori Sangat Baik yaitu berada pada rentang nilai 4.

Persentase ketuntasan belajar siswa kelas VI SDN Sidokare 3 Sidoarjo dalam pembelajaran Matematika materi volume bangun ruang melalui model RME berbasis teori Bruner pada siklus II dari 32 siswa terdapat 94\% atau ada 30 siswa yang sudah tuntas belajar secara klasikal, sedangkan siswa yang belum tuntas sebanyak 2 siswa atau 6\%. Hasil tersebut menunjukkan bahwa pada siklus II secara klasikal siswa sudah tuntas belajar, karena siswa yang memperoleh nilai $\geq 75$ sebesar $94 \%$ melebihi persentase ketuntasan yang dikehendaki. 


\subsection{Pembahasan}

Dari hasil penelitian di atas, selanjutnya dilakukan pembahasan untuk mempermudah menarik kesimpulan terhadap peningkatan hasil belajar Matematika materi volume bangun ruang pada siswa kelas VI SDN Sidokare 3 Sidoarjo sebelum dan sesudah diterapkan model RME berbasis teori Bruner yang dapat dijabarkan sebagai berikut:

\section{Pra Siklus}

Hasil belajar Matematika materi volume bangun ruang siswa kelas VI SDN Sidokare 3 Sidoarjo pada pra siklus masih belum mencapai ketuntasan yang dikehendaki. Hal ini ditunjukkan dari 32 siswa hanya 13 atau 41\% siswa yang mendapatkan nilai di atas KKM yang ditetapkan sekolah yaitu 75, sedangkan sisanya 19 atau $59 \%$ siswa nilainya masih dibawah KKM. Hasil belajar aspek pengetahuan rata-rata sebesar 68 atau kategori Kurang, hasil belajar aspek keterampilan rata-rata sebesar 68 atau kategori Kurang, hasil belajar aspek sikap rata-rata sebesar 2 atau kategori Cukup. Jumlah tersebut masih sangat jauh dari target yang seharusnya dicapai yaitu sebesar $85 \%$ secara klasikal.

Permasalahan tersebut disebabkan karena siswa masih melakukan kesalahan dalam menghitung volume bangun ruang karena belum memahami rumus atau dalil, sebagian siswa kesulitan dalam menghitung volume bangun ruang karena tidak menguasai fakta dasar perkalian dan pembagian. Faktor lain proses pembelajaran yang diterapkan guru masih menerapkan model konvensional, suasana kelas cenderung berpusat pada guru, sehingga siswa menjadi pasif, tidak dapat berpikir kritis, kurang berani untuk bertanya, menjawab pertanyaan, dan mengemukakan pendapatnya saat pembelajaran berlangsung. Guru kurang mengaitkan penyampaian materi pembelajaran dengan permasalahan nyata dalam kehidupan sehari-hari siswa. Hal ini menjadikan siswa kurang diberi kesempatan untuk menyusun pengetahuannya sendiri dalam proses belajarnya.

\section{Siklus I}

Berdasarkan pra siklus tersebut, pada siklus I dilakukan perbaikan dengan menerapkan model RME berbasis teori Bruner dalam pembelajaran Matematika materi volume bangun ruang dapat dikatakan bahwa hasil belajar siswa kelas VI SDN Sidokare 3 Sidoarjo mengalami peningkatan. Hasil belajar aspek pengetahuan pada pra siklus rata-rata sebesar 68 atau kategori Kurang meningkat pada siklus I rata-rata sebesar 79 atau kategori Cukup. Hasil belajar aspek keterampilan pada pra siklus rata-rata sebesar 68 atau kategori Kurang meningkat pada siklus I rata-rata sebesar 79 atau kategori Cukup. Hasil belajar aspek sikap pada pra siklus rata-rata sebesar 2 atau kategori Cukup meningkat pada siklus I rata-rata sebesar 3 atau kategori Baik. Secara klasikal presentase ketuntasan hasil belajar siswa pada prasiklus sebesar $41 \%$ meningkat pada siklus I sebesar $75 \%$. Terbukti ada peningkatan ketuntasan hasil belajar siswa sebesar 34\%. Hasil belajar Matematika materi volume bangun ruang melalui model RME berbasis teori Bruner pada siswa kelas VI SDN Sidokare 3 Sidoarjo mengalami peningkatan, namun hanya mencapai $75 \%$ dan belum mencapai ketuntasan belajar yang dikehendaki sebesar $85 \%$ secara klasikal. 
Peningkatan hasil belajar Matematika materi volume bangun ruang pada siswa kelas VI SDN Sidokare 3 Sidoarjo siklus I disebabkan karena adanya penerapan model RME berbasis teori Bruner meskipun belum mencapai ketuntasan yang dikehendaki. Belum tercapainya ketuntasan belajar siswa secara klasikal disebabkan belum maksimalnya proses pembelajaran Matematika materi volume bangun ruang melalui model RME berbasis teori Bruner yang diterapkan guru dengan presentase sebesar $70 \%$ termasuk kategori Cukup. Hasil pengamatan menunjukkan guru masih kurang memperhatikan tugas tiap siswa pada kelompoknya, ada siswa yang lepas dari tanggung jawabnya. Begitu juga guru masih belum maksimal dalam memotivasi siswa dan mengumpulkan informasi pembelajaran yang berakibat masih ada siswa tidak bertanggung jawab dan disiplin dalam mengerjakan tugas kelompok. Sehingga berdampak masih ada 8 siswa yang kesulitan dalam menghitung volume bangun ruang terutama prisma dan limas. Hal ini dikarenakan jika ada soal berkaitan dengan volume bangun ruang prisma dan limas yang tidak diketahui tinggi atau alasnya, tidak menggunakan dalil atau rumus phytagoras namun langsung menggunakan rumus volume.

\section{Siklus II}

Setelah melakukan perbaikan pembelajaran Matematika materi volume bangun ruang melalui penerapan model RME berbasis teori Bruner pada siklus II dan melaksanakan hasil rekomendasi siklus I dapat dikatakan bahwa hasil belajar siswa kelas VI SDN Sidokare 3 Sidoarjo mengalami peningkatan yang signifikan. Hasil belajar aspek pengetahuan pada pra siklus rata-rata sebesar 68 atau kategori Kurang, siklus I rata-rata sebesar 79 atau kategori Cukup, dan siklus II rata-rata sebesar 90 atau kategori Baik. Hasil belajar aspek keterampilan pada pra siklus rata-rata sebesar 68 atau kategori Kurang, siklus I rata-rata sebesar 79 atau kategori Cukup, dan siklus II rata-rata sebesar 90 atau kategori Baik. Hasil belajar aspek sikap pada pra siklus rata-rata sebesar 2 atau kategori Cukup, siklus I ratarata sebesar 3 atau kategori Baik, dan siklus II rata-rata sebesar 4 atau kategori Sangat Baik. Secara klasikal presentase ketuntasan pada prasiklus sebesar $41 \%$, siklus I sebesar 75\%, dan siklus II sebesar 94\%. Terbukti ada peningkatan ketuntasan hasil belajar siswa sebesar 53\%. Hasil belajar Matematika materi volume bangun ruang melalui model RME berbasis teori Bruner pada siswa kelas VI SDN Sidokare 3 Sidoarjo mengalami peningkatan secara signifikan sebesar 94\% dan sudah melebihi ketuntasan belajar yang dikehendaki sebesar $85 \%$ secara klasikal.

Peningkatan hasil belajar Matematika materi volume bangun ruang pada siswa kelas VI SDN Sidokare 3 Sidoarjo siklus II disebabkan karena adanya penerapan model RME berbasis teori Bruner. Tercapainya ketuntasan belajar siswa secara klasikal disebabkan guru sudah maksimal dalam menerapkan proses pembelajaran Matematika materi volume bangun ruang melalui model RME berbasis teori Bruner dengan presentase sebesar 95\% dan termasuk kategori Sangat Baik. Hal ini dikarenakan pada siklus II guru sudah melaksanakan hasil refleksi siklus I. Pada siklus II guru membimbing kelompok yang mengalami kesulitan. Guru mampu meningkatkan kesadaran siswa akan tanggung jawabnya dalam kelompok. Hal ini menjadikan siswa mampu menyelesaikan masalah kontekstual dengan baik. Berkat bimbingan serta penguatan dari guru, siswa lebih 
bertanggung jawab, disiplin dan percaya diri dalam menyelesaikan masalah kontekstual. Terbukti dari 30 siswa mampu menentukan volume gabungan dari beberapa bangun ruang terutama prisma dan limas jika tidak diketahui tinggi atau alasnya serta sudah memahami dalil atau rumus phytagoras sebelum mencari volumenya. Hal ini dikarenakan guru menginstruksikan kepada siswa untuk mengukur sendiri benda konkrit berbentuk bangun ruang sehingga siswa dapat menemukan sendiri konsep volume bangun ruang.

Dengan demikian penerapan model pembelajaran RME berbasis teori Bruner terbukti efektif dan dapat meningkatkan hasil belajar Matematika materi volume bangun ruang pada siswa kelas VI SDN Sidokare 3 Sidoarjo yang dibuktikan dari ketuntasan belajar dan nilai rata-rata hasil belajar siswa yang semakin meningkat dan melebihi ketuntasan yang dikehendaki. Hal tersebut sesuai dengan pendapat Aisyah, dkk (2010:7.1) menjelaskan bahwa dengan menerapkan model RME, siswa dapat membangun sendiri pengetahuan sehingga siswa tidak mudah lupa dengan pengetahuannya, suasana proses pembelajaran menyenangkan karena menggunakan realitas kehidupan sehingga siswa tidak cepat bosan belajar matematika, memupuk kerja sama dalam kelompok, melatih keberanian siswa dalam menjelaskan jawabannya, dan melatih siswa untuk terbiasa berpikir dan mengemukakan pendapat. Selain itu dengan menerapkan teori Bruner sebagaimana pendapat (Karso, 2014:1.12) melalui tahap enaktif (enactive), anak dapat memanipulasikan, menyusun, menjejerkan, mengutak-atik, dan bentuk-bentuk gerak lainnya menggunakan benda-benda nyata (konkrit). Selanjutnya tahap ikonik (iconic), anak telah mengubah, menandai, dan menyimpan peristiwa atau benda dalam bentuk bayangan mental (gambar). Pada tahap simbolik (symbolic), anak sudah mampu memahami simbol-simbol dan menjelaskan dengan bahasanya.

Berdasarkan hasil penelitian dan pembahasan di atas menunjukkan bahwa dengan menerapkan model RME berbasis teori Bruner terbukti dapat meningkatkan hasil belajar Matematika materi volume bangun ruang pada siswa kelas VI SDN Sidokare 3 Sidoarjo. Dari hasil penelitian tersebut, penelitian ini sudah dapat dikatakan berhasil, hal ini dikarenakan hasil evaluasi Matematika materi volume bangun ruang dalam bentuk masalah kontekstual yang diberikan kepada seluruh siswa pada siklus I dan II menunjukkan adanya peningkatan yang sangat signifikan dan sudah melebihi ketuntasan yang dikehendaki.

\section{PENUTUP}

\subsection{Kesimpulan}

Berdasarkan hasil penelitian dan pembahasan yang dikemukakan pada bab sebelumnya, dapat disimpulkan bahwa: 1) Penerapan model RME berbasis teori Bruner terbukti efektif diterapkan pada pembelajaran Matematika materi volume bangun ruang pada siswa kelas VI SDN Sidokare 3 Sidoarjo. Hal ini terlihat dari ketuntasan belajar siswa pada pra siklus memperoleh persentase sebesar $41 \%$, meningkat pada siklus I sebesar $75 \%$, dan meningkat pada siklus II sebesar $94 \%$. Terbukti ada peningkatan ketuntasan belajar siswa sebesar 53\%; 2) Penerapan model RME berbasis teori Bruner terbukti dapat meningkatkan hasil belajar Matematika materi volume bangun ruang pada siswa kelas VI SDN Sidokare 3 
Sidoarjo. Hal ini terlihat dari nilai rata-rata hasil belajar aspek pengetahuan pada pra siklus sebesar 68 atau kategori Kurang, siklus I sebesar 79 atau kategori Cukup, dan siklus II sebesar 90 atau kategori Baik. Hasil belajar aspek keterampilan pada pra siklus sebesar 68 atau kategori Kurang, siklus I sebesar 79 atau kategori Cukup, dan siklus II sebesar 90 atau kategori Baik. Hasil belajar aspek sikap pada pra siklus sebesar 2 atau kategori Cukup, siklus I sebesar 3 atau kategori Baik, dan siklus II sebesar 4 atau kategori Sangat Baik.

\subsection{Saran}

Berdasarkan kesimpulan hasil penelitian tersebut, dapat dijabarkan saran tindak lanjut sebagai berikut: 1) Disarankan kepada siswa untuk lebih berlatih menyelesaikan soal pemecahan masalah kontekstual Matematika materi volume bangun ruang sendiri seperti penerapan model RME berbasis teori Bruner yang sudah dilaksanakan di kelas sehingga hasil belajar siswa dapat meningkat; 2) Disarankan kepada guru untuk menerapkan model RME berbasis teori Bruner dalam pembelajaran Matematika yang terbukti dapat meningkatkan hasil belajar siswa. Disarankan juga kepada teman sejawat untuk menggunakan model dan teori pembelajaran yang mengutamakan peran aktif siswa sehingga mutu pembelajaran di kelas dapat meningkat; 3) Disarankan kepada sekolah untuk memberikan kesempatan kepada guru untuk meningkatkan kompetensi dan profesionalismenya dalam menguasai model dan teori pembelajaran yang mendidik sehingga kualitas pembelajaran di sekolah dapat lebih meningkat.

\section{DAFTAR PUSTAKA}

Aisyah, Nyimas, dkk. 2010. Pengembangan Pembelajaran Matematika SD. Jakarta: Direktorat Jenderal Pendidikan Tinggi, Depdiknas.

Anitah, W. Sri., dkk. 2014. Strategi Pembelajaran di SD-Cet.21;Ed.1. Tangerang Selatan: Universitas Terbuka.

Djamarah, B. Saeful. 2015. Guru dan Anak Didik dalam Interaksi Edukatif. Jakarta: Rineka Cipta.

Hernawan, H. Asep., dkk. 2016. Pengembangan Kurikulum dan Pembelajaran di SD-Cet.6;Ed.1. Tangerang Selatan: Universitas Terbuka.

Karso, dkk. 2014. Pendidikan Matematika 1-Cet.18;Ed.1. Tangerang Selatan: Universitas Terbuka.

Kemendikbud. 2017. Model Silabus Mata Pelajaran Matematika. Jakarta: Kementerian Pendidikan dan Kebudayaan Republik Indonesia.

Permendikbud Nomor 57 Tahun 2014 tentang Kurikulum 2013 SD/MI. Jakarta: Kemendikbud.

Permendiknas Nomor 16 Tahun 2007 tentang Standar Kualifikasi Akademik dan Kompetensi Guru. Jakarta: Depdiknas.

Sudjana, Nana. 2017. Penilaian Hasil Proses Belajar Mengajar-Cet.21. Bandung: PT. Remaja Rosdakarya.

Sugiyono. 2013. Metode Penelitian Pendidikan-Cet.19. Bandung: Alfabeta.

Sukajati. 2012. Penelitian Tindakan Kelas. Yogyakarta: P4TK Matematika, Dirjen PMPTK, Depdiknas. 
Unisda Journal of Mathematics and Computer Science Jurusan Matematika, UNISDA, Lamongan

Winataputra, S. Udin, dkk. 2016. Teori Belajar dan Pembelajaran-Cet.18;Ed.1. Tangerang Selatan: Universitas Terbuka. 